DOI

UDC: $616.8-008.615 .1-06: 616.329 / .33-007.271$

\title{
STRESS AND GASTROESOPHAGEAL REFLUX DISEASE
}

\author{
Dalbir S Sandhu, Ronnie Fass \\ Division of Gastroenterology and Hepatology, Department of Medicine \\ MetroHealth Medical Center and Case Western Reserve University \\ Cleveland, Ohio, USA, ronnie.fass@gmail.com
}

\begin{abstract}
Gastroesophageal reflux disease (GERD) is one of the commonest conditions managed by clinicians. Regurgitation and heartburn are considered the cardinal symptoms of GERD. In recent decades, an increasing association has been noted between stress and GERD and our knowledge about the pathophysiology of this relationship is constantly evolving. Both acute and chronic stress can accentuate GERD related symptoms. Subjects exposed to chronic life stressors are more likely to complaint of GERD symptoms. Current data suggests that acute stress exacerbates GERD symptoms by enhancing the perceptual responses to intra-esophageal acid stimulivia central mechanisms without increasing the amount of acid reflux. This process is likely mediated by an increase in esophageal mucosal permeability. Treatment with proton pump inhibitors attenuates the effect of acute stress on esophageal perception thresholds for pain. However, the effect of anti-reflux therapy in patients experiencing chronic stress remains to be elucidated.
\end{abstract}

Disclosures. No conflicts of interest, financial or otherwise, are declared by the authors.

Author contribution. Dalbir S Sandhu drafted manuscript; Ronnie Fass approved final version of the manuscript.

Key words: Esophageal hypersensitivity, gastroenterology, gastroesophageal reflux disease, stress.

\section{СТРЕС I ГАСТРОЕЗОФАГЕАЛЬНА РЕФЛЮКСНА ХВОРОБА}

\author{
Далбір С. Сандху, Ронні Фасс \\ Відділення гастроентерології та гепатології відділу медицини \\ Медичний центр MetroHealth і Західний резервний університет Кейса \\ Клівленд, Огайо, США, ronnie.fass@gmail.com
}

Гастроезофагеальна рефлюксна хвороба (ГЕРХ) - одне з найпоширеніших захворювань, 3 яким мають справу лікарі. Відригування та печія вважаються основними симптомами ГЕРХ. Упродовж останніх років між стресом і ГЕРХ помічено все більший зв'язок, а наші знання про патофізіологію цього зв'язку постійно розвиваються. Гострий і хронічний стрес можуть посилювати симптом ГЕРХ. Пацієнти, що зазнають впливу хронічних стресових чинників частіше скаржаться на симптоми ГЕРХ. Поточні дані показують, що гострий стрес посилює симптоми ГEPХ, підвищуючи чутливість до подразників внутрішньоезофагеальної кислоти через центральні механізми, не збільшуючи кислотний рефлюкс. Цей процес, імовірно, спричинений збільшенням проникності оболонки стравоходу. Лікування за допомогою протонної помпи послаблює вплив гострого стресу на пороги сприйняття болю стравоходом. Однак вплив антирефлюксної терапії в пацієнтів, що страждають від хронічного стресу, досі не з'ясований.

Ключові слова: Езофагеальна гіперчутливість, гастроентерологія, гастроезофагеальна рефлюксна хвороба, стрес. 


\section{Introduction}

Gastroesophageal reflux disease (GERD) is defined as symptoms or complications resulting from the reflux of gastric contents into the esophagus or beyond, into the oropharynx, larynx and pulmonary system (1). The primary symptoms of GERD are regurgitation and heartburn although symptoms such as water brash, chest pain, belching, dysphagia, epigastric pain, nausea, vomiting, cough, hoarseness, throat clearing, and throat pain are other clinical presentations of GERD either solely or in conjunction with the primary symptoms(2).

In recent decades, an increasing association has been proposed between stress and GERD (table 1). Stress is defined as any uncomfortable emotional experience accompanied by predictable biochemical, physiological and behavioral changes. Some stress also called 'eustress'can boost up drive, energy, and performance. However, excessive stress can be detrimental, leading to health consequences affecting the immune, cardiovascular, central nervous, and neuroendocrine system(3).

Studies have suggested that unhealthy stress management by eating 'comfort foods' is contributing to the rising epidemic of obesity(4). Apart from insomnia, obesity and other disorders, it has been suggested that persons subjected to stressors complain more often of GERD related symptoms(5-7). In fact, more than two-third of GERD patients report that stress exacerbate their symptoms (7). Similarly, chronic or severe GERD can lead to stress per se. Thus the relationship could be bidirectional where stress can lead to GERD and GERD can lead to stress(8).

There is large amount of data that is focused on the relationship between stress and GERD. However, prior to any conclusion, it is important to understand the type of stressor used. Different types of stressors have been used in these studies and include loud noises, white noise, exposure to cold temperature, anticipation of stressful situation, and others. These are primarily models of acute stress and very few of chronic stress. Developing models of chronic stress, which more closely resembles patients' life experience, has been a significant challenge. Example of chronic stress models used in the literature include subjects experiencing prolonged stressful situation such as caring for loved ones who are terminally ill. It is important to note that persons who have been exposed to chronic stress are more likely to complain of GERD symptoms.

In this review, we discuss the evolving understanding about the relationship between

Table 1

\section{Studies showing the effect of stress on patients with GERD}

\begin{tabular}{|c|c|c|c|c|}
\hline $\begin{array}{c}\text { Serial } \\
\text { number }\end{array}$ & Study & Subjects & Type of Stress & Results \\
\hline 1 & $\begin{array}{l}\text { Hemmink GJ, } \\
\text { et al (26) }\end{array}$ & $\begin{array}{l}15 \text { normal volunteers } \\
10 \text { GERD patients }\end{array}$ & $\begin{array}{c}\text { Acute psychological } \\
\text { stress induced by IQ } \\
\text { test }\end{array}$ & $\begin{array}{l}\text { No increase in esophageal acid } \\
\text { perception between subjects }\end{array}$ \\
\hline 2 & $\begin{array}{c}\text { Fass R } \\
\text { et al (20) }\end{array}$ & $\begin{array}{l}10 \text { normal volunteers } \\
46 \text { heartburn patients }\end{array}$ & Auditory stress & $\begin{array}{l}\text { GERD patients reported en- } \\
\text { hanced perceptual response to } \\
\text { intra-esophageal acid exposure } \\
\text { compared to healthy subjects }\end{array}$ \\
\hline 3 & $\begin{array}{l}\text { Wright CE } \\
\text { et al (16) }\end{array}$ & $\begin{array}{l}42 \text { patients with heart- } \\
\text { burn/acid regurgitation } \\
\text { ( } 21 \text { received stressor) }\end{array}$ & Psychological stressor & No increase in reflux \\
\hline 4 & $\begin{array}{l}\text { Johnston BT } \\
\text { et al (27) }\end{array}$ & 60 patients & $\begin{array}{l}\text { Psychological stress } \\
\text { (Stroop test) and } \\
\text { physical stress (cold } \\
\text { pressor test) }\end{array}$ & $\begin{array}{l}\text { No changes in esophageal motili- } \\
\text { ty in response to stressor }\end{array}$ \\
\hline 5 & $\begin{array}{l}\text { Bradley LA } \\
\text { et al (7) }\end{array}$ & 17 patients with GERD & Stress tasks & $\begin{array}{l}\text { No increase in total acid expo- } \\
\text { sure, number of reflux episodes, } \\
\text { duration of longest reflux episode }\end{array}$ \\
\hline
\end{tabular}


GERD and stress and attempt to hypothesize, why acute and chronic stress trigger GERD related symptoms.

\section{Stress and heartburn symptoms}

One of the cardinalpresentations of GERD is heartburn. In a study of 60 subjects with current heartburn, Naliboff et al showed that the presence of a severe, sustained life stress during the previous 6 months significantly predicted increased heartburn symptoms during the following 4 months(9). It was found that 'vital exhaustion', which is a measure of sustained stress, was mostly correlated with heartburn. The authors proposed increased level and frequency of esophageal acid exposure, inhibition of gastric emptying of acid, or stress-induced esophageal hypersensitivity as potential mechanisms of worsening heartburn symptoms in subjects with stress. Another large-scale study from Japan interviewed 12,653 patients with GERD who were on proton pump inhibitor therapy with a validated questionnaire. The study found that «feelings of continued stress» was the most common lifestyle factor (45.6\% of patients) associated with GERD related symptoms(10). In a Gallup survey, $64 \%$ of the GERD patients reported that stress exacerbates their symptoms (11). Stress can alter health related behaviors such as increase in smoking, alcohol consumption, insomnia, comfort foods consumption and physical inactivity. This in turn can exacerbate GERD. Alcohol and cigarette smoking can decrease the lower esophageal sphincter basal pressure and consequently exacerbate $\operatorname{GERD}(12,13)$.

Interestingly, in a study that included 50 subjects with typical and atypical (non cardiac chest pain) symptoms of GERD, it was noted that proximal esophageal extension of acid during reflux episodes was more common in patients with atypical symptoms of GERD and patients with worse anxiety scores. This study highlights the role of stress in also leading to atypical presentations of GERD (14).

The aforementioned studies clearly demonstrated that stress exacerbates GERD related symptoms. However, the mechanism by which stress exacerbates GERD remains to be fully elucidated.

\section{Stress and intra-esophageal acid exposure}

One of the early proposed mechanism on how stress leads or exacerbates GERD related symptoms was increase in gastroesophageal reflux. It has also been proposed that stress decreases lower esophageal sphincter tone leading to increased symptoms of GERD (15). However, a number of studies were unable to demonstrate that stress increases intra-esophageal acid exposure. One of the first controlled trialsthat assessed the effect of psychosocial stress on GERD (acid reflux parameters, and perceptions of reflux symptoms) was reported by Bradley et al(7). There was a significant increase in anxiety and reflux symptoms in subjects with GERD when exposed to stress provoking tasks. However, objective parameters of acid reflux (total esophageal acid exposure, number of reflux episodes, and duration of longest reflux episode) remained unchanged. These subjects' reflux ratings remained at high levels during all stress periods, whereas subjects in all other experimental conditions reported decreased reflux symptoms across periods. These results suggested that reflux patients who are chronically anxious and exposed to prolonged stress may perceive low intensity esophageal stimuli as painful reflux symptoms (7). A similar study in 42 subjects with heartburn and acid regurgitation who underwent 24 hour esophageal $\mathrm{pH}$ monitoring found no increase in esophageal acid exposure or reflux in the stressor group despite an increase in cortisol levels(16). In this study, 21 subjects received a stressor during the last 90 minutes of $\mathrm{pH}$ monitoring while the other 21 were randomly assigned to a no-stress control situation. Interestingly, dissociation was noted between objectively measured reflux episodes and subjective symptom ratings.

Overall, the aforementioned studies suggest that the close association between stress and GERD is not through increase in esophageal acid exposure or related parameters.

\section{Stress and reflux esophagitis}

Even though the above mentioned studies suggested no relation between stress and amount of esophageal acid reflux or exposure, stress is believed to induce reflux esophagitis 
by increasing esophageal mucosal permeability (Fig. 1). In an experimental rat model, acute stress increased submucosal mast cells and acid pepsin induced mucosal permeability(17). An assessment under electron microscopy showed increase in dilated intercellular spaces of the esophageal mucosa of stressed rats. A large cohort study involving 6834 patients from Korea showed significant association between stress and reflux esophagitis (odds ratio 1.94 , 95\% CI 1.25-3.02). Interestingly, the severity of reflux esophagitis correlated with the degree of stress. Unfortunately, this studyhad two main limitations, first, responder bias as self-report system was used to collect the data and second, selection bias since the study enrolled only those patients who underwent medical check ups (18).

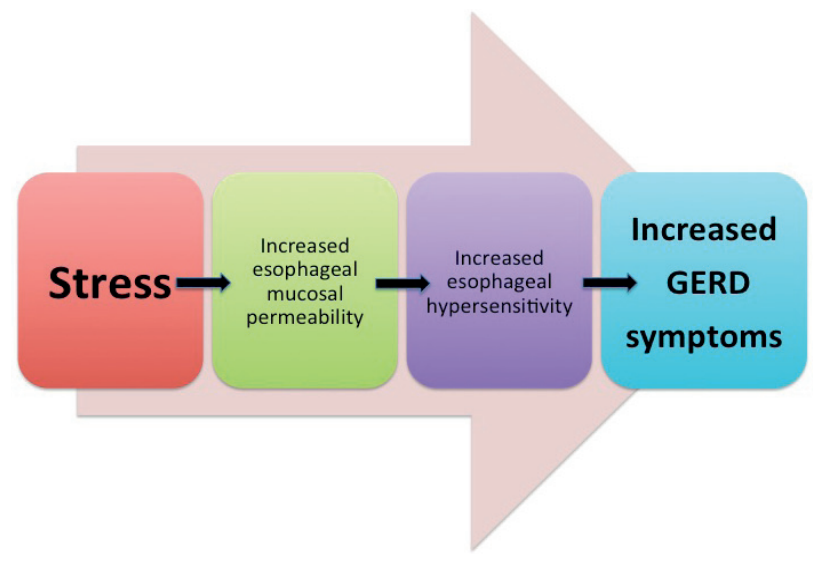

Fig. 1. Proposed mechanism for stress leading to GERD

\section{Stress and gastric acid secretion}

In an early study that assessed the effect of stress on gastric acid secretion, the authors induced acute mental (psychomotor) stress in 14 subjects and evaluated gastric acid output secretion. Even though a significant increase in systolic blood pressure and heart rate were observed in response to stress, the mean gastric acid output secretion (17.9 +/- 2.7 $\mathrm{mmol} / 32 \mathrm{~min}$ ) did not significantly differ from pre- $(16.9+/-2.3 \mathrm{mmol} / 32 \mathrm{~min})$ and post stress (18.1 +/- $2.2 \mathrm{mmol} / 32 \mathrm{~min})$ values. Further analysis showed that mental stress induced contradictory changes of gastric acid output in different subjects with $50 \%$ of the individuals reacted with a decrease (up to $60 \%$ ) and the other half with an increase (up to $60 \%$ ) in acid output. This study concluded that stress had variable effects on gastric acid output in different subjects(5). Similar results showing lack of effect on gastric acid flow and output in response to stress has been shown by other investigators(19).

\section{Stress and esophageal hypersensitivity}

Esophageal hypersensitivity as the driving underlying mechanism for the relationship between stress and GERD was also proposed. In a pivotal trial, the authors assessed the effect of an acute auditory stressor on perceptual and emotional responses to intra-esophageal acid perfusion in healthy controls and patients with GERD.The authors recruited 46 patients with heartburn and 10 healthy subjects. Of the 46 patients 29 had non-erosive reflux disease and 17 had erosive esophagitis. Perceptual and emotional responses to intra-esophageal acid at baseline, during auditory stress, and during an auditory control condition were determined using a randomized crossover design. It was found that acute auditory stress can exacerbate heartburn symptoms in GERD patients by enhancing perceptual response to intra-esophageal acid exposure. Theincrease perceptual response was associated with greater emotional responses to the stressor (20).

While this study was an acute stress model, it is biologically plausible that subjects who are chronically anxious and exposed to prolonged stressful stimuli may be more likely to perceive low-intensity esophageal stimuli as being painful(7). It is likely that central mechanisms are responsible for enhancing perception of peripheral (esophageal) stimuli. These findings were also noted in healthy volunteers where anxiety induction increased acid-induced esophageal hyperalgesia without actually increasing esophageal acid exposure thus suggesting that anxiety promotes central sensitization of intra-esophageal stimuli (21).

\section{Stress related sleep deprivation and GERD}

A common phenotype of stress is sleep deprivation or insomnia. GERD per se can lead to sleep deprivation because of nighttime reflux that is associated with arousals or awakenings from sleep. However, sleep deprivation by itself can worsen GERD symptoms. To understand this pathophysiology, a prospective, randomized controlled trial was done in 10 healthy controls and 10 GERD patients with erosive esophagitis. The study reported a significantly shorter mean 
lag time to reported heartburn symptoms during esophageal acid perfusion in GERD patients who were sleep deprived, compared with those who experienced sufficient sleep. GERD patients demonstrated a significant decrease in lag time to symptom report (91 +/- 21.6 vs $282.7+/-67 \mathrm{sec}$, respectively, $\mathrm{P}=.02)$, increase in intensity rating $(9.3+/-$ 1.4 vs $4.4+/-0.9 \mathrm{~cm}$, respectively, $\mathrm{P}=.02$ ), and increase in acid perfusion sensitivity score $(48.3+/-8.5$ vs 22.7 +/- $4.5 \mathrm{sec} x \mathrm{~cm} / 100$, respectively, $\mathrm{P}=.02$ ) after sleep deprivation as compared with nights of good sleep. Normal subjects did not demonstrate any differences in stimulus response functions to acid between sufficient sleep and sleep deprivation (578 +/164 vs $493.8+/-60.3 \mathrm{sec}, 0.3+/-0.2$ vs 0.45 +/- $0.2 \mathrm{~cm}$, and $0.4+/-0.3$ vs $2.4+/-1.4$ sec $x \mathrm{~cm} / 100$, respectively, all $P=N S$ ). This study was the first to demonstrate that sleep deprivation by itself can modulate esophageal perception thresholds for pain in patients with $\operatorname{GERD}(22)$.

\section{Stress and antireflux treatments in GERD}

The association between acute stress and exacerbation of heartburn in GERD patients via enhancement of perceptual responses to intraesophageal acid has been demonstrated. Consequently, it was hypothesized thatantireflux treatment can alter stimulus response functions to acid in patients with stress. Poh et al evaluatedsymptomatic GERD patients with erosive esophagitis or an abnormal $\mathrm{pH}$ test by giving them esomeprazole $40 \mathrm{mg}$ daily over a period of 8 weeks(23). The primary aim was to assess if this dose attenuates the effect of acute stress on stimulus-response functions to acid of patients with GERD as compared with placebo. The study also determined the clinical predictive factors for response to esomeprazole $40 \mathrm{mg}$ daily in GERD patients undergoing stressful stimulus. The authors demonstrated that treatment with a PPI significantly reduced esophageal perceptual responses to acid even during an acute stressful stimulus. Interpersonal sensitivity was the sole predictor for response to antireflux treatment during acute stress. Another study evaluated the effect of psychomotor distress on response to PPI in patients with GERD. Subjects were divided into 3 groups; responders to PPI once daily, non-responders to PPI once daily and non-responders to PPI twice daily. Of the 245 patients enrolled in this study, no differences were observed among the groups with respect to age, sex, psychiatric medications or preexisting major depression. However, lack of response to PPI treatment was associated with lower life satisfaction but not anxiety or depression (24). A multicenter, multinational, prospective trial attempted to predict response to PPI and determine factors influencing treatment outcomes in patients with GERD. The authors reported that poorer treatment responses were associated with anxiety and concurrent irritable bowel syndrome before treatment(25).

\section{Conclusions}

Both acute and chronic stress can exacerbate GERD related symptoms. There is no evidence for increase in intra-esophageal acid exposure or gastric acid secretion in response to stress, however acute stress can exacerbate GERD symptoms by modulating perception threshold for pain. It is possible that the latter phenomenon is the result of increase in esophageal mucosal permeability. Importantlystress induced esophageal hypersensitivity can be attenuated by the use of proton pump inhibitors in patients experiencing acute stress. However, the effect of anti-reflux treatment in patients experiencing chronic stress remains to be elucidated.

Disclosures. No conflicts of interest, financial or otherwise, are declared by the authors.

Author contribution. Dalbir S Sandhu drafted manuscript; Ronnie Fass edited and approved final version of the manuscript.

\section{References}

1. Katz P.O., Gerson L.B., Vela M.F. Guidelines for the diagnosis and management of gastroesophageal reflux disease. Am J Gastroenterol. 2013;108(3):308-28; quiz 29.

2. Sandhu D.S., Fass R. Current Trends in the Management of Gastroesophageal Reflux Disease. Gut Liver. 2018;12(1):7-16.

3. Anderson N.B. Levels of analysis in health science. A framework for integrating sociobehavioral and biomedical research. Ann N Y Acad Sci. 1998;840:563-76. 
4. Dallman M.F., Pecoraro N., Akana S.F., La Fleur S.E., Gomez F., Houshyar H., et al. Chronic stress and obesity: a new view of «comfort food». Proc Natl Acad Sci U S A. 2003;100(20):11696-701.

5. Holtmann G., Kriebel R., Singer M.V. Mental stress and gastric acid secretion. Do personality traits influence the response? Dig Dis Sci. 1990;35(8):998-1007.

6. Rubin J., Nagler R., Spiro H.M., Pilot M.L. Measuring the effect of emotions on esophageal motility. Psychosom Med. 1962;24:170-6.

7. Bradley L.A., Richter J.E., Pulliam T.J., Haile J.M., Scarinci I.C., Schan C.A., et al. The relationship between stress and symptoms of gastroesophageal reflux: the influence of psychological factors. Am J Gastroenterol. 1993;88(1):11-9.

8. Kulig M., Leodolter A., Vieth M., Schulte E., Jaspersen D., Labenz J., et al. Quality of life in relation to symptoms in patients with gastro-oesophageal reflux disease-- an analysis based on the ProGERD initiative. Aliment Pharmacol Ther. 2003;18(8):767-76.

9. Naliboff B.D., Mayer M., Fass R., Fitzgerald L.Z,. Chang L., Bolus R., et al. The effect of life stress on symptoms of heartburn. Psychosom Med. 2004;66(3):426-34.

10. Haruma K., Kinoshita Y., Sakamoto S., Sanada K., Hiroi S., Miwa H. Lifestyle factors and efficacy of lifestyle interventions in gastroesophageal reflux disease patients with functional dyspepsia: primary care perspectives from the LEGEND study. Intern Med. 2015;54(7):695-701.

11. A gallup survey on heartburn across America.. Princeton, NJ Gallup Organization Inc. 1988.

12. Kahrilas P.J., Gupta R.R. Mechanisms of acid reflux associated with cigarette smoking. Gut. 1990;31(1):4-10.

13. Vitale G.C., Cheadle W.G., Patel B., Sadek S.A., Michel M.E., Cuschieri A. The effect of alcohol on nocturnal gastroesophageal reflux. JAMA. 1987;258(15):2077-9.

14. Shapiro M., Simantov R., Yair M., Leitman M., Blatt A., Scapa E., et al. Comparison of central and intraesophageal factors between gastroesophageal reflux disease (GERD) patients and those with GERDrelated noncardiac chest pain. Dis Esophagus. 2012;25(8):702-8.

15. Mittal R.K., Stewart W.R., Ramahi M., Chen J., Tisdelle D. The effects of psychological stress on the esophagogastric junction pressure and swallow-induced relaxation. Gastroenterology. 1994;106(6):1477-84.

16. Wright C.E., Ebrecht M., Mitchell R., Anggiansah A., Weinman J. The effect of psychological stress on symptom severity and perception in patients with gastro-oesophageal reflux. J Psychosom Res. 2005;59(6):415-24.

17. Peterson W.L. The role of acid in upper gastrointestinal haemorrhage due to ulcer and stress-related mucosal damage. Aliment Pharmacol Ther. 1995;9 Suppl 1:43-6.

18. Song E.M., Jung H.K., Jung J.M. The association between reflux esophagitis and psychosocial stress. Dig Dis Sci. 2013;58(2):471-7.

19. Holtmann G., Singer M.V., Kriebel R., Stacker K.H., Goebell H. Differential effects of acute mental stress on interdigestive secretion of gastric acid, pancreatic enzymes, and gastroduodenal motility. Dig Dis Sci. 1989;34(11):1701-7.

20. Fass R., Naliboff B.D., Fass S.S., Peleg N., Wendel C., Malagon I.B., et al. The effect of auditory stress on perception of intraesophageal acid in patients with gastroesophageal reflux disease. Gastroenterology. 2008;134(3):696-705.

21. Sharma A., Van Oudenhove L., Paine P., Gregory L., Aziz Q. Anxiety increases acid-induced esophageal hyperalgesia. Psychosom Med. 2010;72(8):802-9.

22. Schey R., Dickman R., Parthasarathy S., Quan S.F., Wendel C., Merchant J., et al. Sleep deprivation is hyperalgesic in patients with gastroesophageal reflux disease. Gastroenterology. 2007;133(6):1787-95.

23. Poh C.H., Hershcovici T., Gasiorowska A., Navarro-Rodriguez T., Willis M.R., Powers J., et al. The effect of antireflux treatment on patients with gastroesophageal reflux disease undergoing a mental arithmetic stressor. Neurogastroenterol Motil. 2011;23(11):e489-96.

24. Boltin D., Boaz M., Aizic S., Sperber A., Fass R., Niv Y., et al. Psychological distress is not associated with treatment failure in patients with gastroesophageal reflux disease. J Psychosom Res. 2013;75(5):462-6.

25. Heading R.C., Monnikes H., Tholen A., Schmitt H. Prediction of response to PPI therapy and factors influencing treatment outcome in patients with GORD: a prospective pragmatic trial using pantoprazole. BMC Gastroenterol. 2011;11:52.

26. Hemmink G.J., Bredenoord A.J., Weusten B.L., Timmer R., Smout A.J. Does acute psychological stress increase perception of oesophageal acid? Neurogastroenterol Motil. 2009;21(10):1055-e86.

27. Johnston B.T., McFarland R.J., Collins J.S., Love A.H. Effect of acute stress on oesophageal motility in patients with gastro-oesophageal reflux disease. Gut. 1996;38(4):492-7.

Стаття надійшла 14.09.2018

Після допрацювання 15.11.2018

Прийнята до друку 27.12.2018 